\title{
МОРФОЛОГІЧНІ ЗМІНИ ТКАНИН ТОНКОЇ КИШКИ, ПЕЧІНКИ І СЕРЦЯ ПРИ ЗАСТОСУВАННІ КАРАГІНАНУ В ЕКСПЕРИМЕНТІ
}

\begin{abstract}
Резюме. На думку багатьох учених, зменшення кількості споживання свіжих харчових продуктів, органічної їжі й збільшення штучних харчових домішок може бути однією з причин зростання поширеності великої кількості захворювань.

Мета дослідження - вивчити структурну організацію стінки тонкої кишки, міокарда і печінки експериментальних тварин при застосуванні $1 \%$ розчину к-карагінану.

Матеріали і методи. Дослідження проведено на 24 статевозрілих білих нелінійних щурах-самцях. Тваринам дослідної групи був забезпечений вільний доступ до 1,0 \% розчину карагінану в питній воді упродовж одного місяця.

Результати досліджень та їх обговорення. При мікроскопічному дослідженні внутрішніх органів експериментальних тварин найвираженішими зміни були у тонкій кишці. Домінуючим елементом у картині патологічних змін виявили прояви хронічного ентериту - інфрільтрація слизової оболонки лімфоцитами, макрофагами, гістіоцитами, нейтрофрілами, еозинофілами. Застосування карагінану зумовлювало зміни морфологічної картини в печінці й серці. Подекуди мали місце помірно виражені альтеративні зміни гепатоцитів, у перипортальних зонах спостерігали наявність двоядерних гепатоцитів, що свідчить про репаративну регенерацію в паренхімі печінки. Зміни серцевого м'яза у піддослідних тварин були виражені помірно. Спостерігався помірно виражений набряк, місцями повнокров'я судин та наявність поодиноких еритроцитів у перивазальних ділянках. Також подекуди були вогнищеві скупчення лімфоцитів.

Висновки. Ушкодження епітеліоцитів та їх дистрофрія, дезорганізація сполучнотканинних елементів підслизового шару тонкої кишки при застосуванні 1 \% карагінану призводить до морфологічних змін у печінці (дистрофрічні зміни гепатоцитів) і серці (помірно виражений набряк і вогнищеві скупчення лімфоцитів у міокарді).
\end{abstract}

Ключові слова: карагінан; тонка кишка; печінка; серце; структурна організація.

ВСТУП Активне зростання харчової промисловості привело до того, що хімічні добавки стали частиною нашого щоденного раціону. На думку багатьох вчених, зменшення кількості споживання свіжих харчових продуктів, органічної їжі й збільшення штучних харчових домішок можуть бути однією з причин зростання поширеності великої кількості захворювань, у тому числі раку, цукрового діабету, ожиріння, депресії і бронхіальної астми [1].

Серед великої кількості харчових добавок гідроколоїди використовують у виробництві м'ясної і молочної продукції через структуроутворювальні, вологоутримувальні, стабілізуювальні властивості. Гідроколоїди, у тому числі й карагінани, входять у список харчових і лікарських препаратів [2]. Карагінан належить до сульфратованих полісахаридів червоних водоростей, в основі хімічної структури яких знаходиться повторювана дисахаридна ланка, що складається із залишків

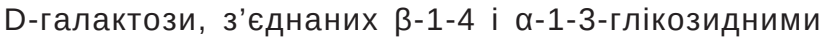
зв'язками, що чергуються. Результати досліджень багатьох років вказують на противиразкову, антикоагулянтну, протипухлинну і противірусну дії [3]. Проте існують і протилежні дані. Згідно з дослідженнями А. С. Ткаченка, харчова добавка карагінан або E407 може бути потенційним етіологічним чинником хронічних запальних захворювань кишечника. Карагінан, при потраплянні в організм, здатний спричинити виражену запальну й алергічну реакції, що пов'язано з підвищеним викидом медіаторів запалення (гістаміну, серотоніну, брадикініну) і простагландинів, особливо простагландину E2 [4]. Медіатори запалення спричиняють розширення судин, підвищення місцевого кровотоку і проникності судинної стінки, що призводить до набряку і збільшеного виходу лейкоцитів із судинного русла [5]. Результати досліджень інших авторів вказують на розвиток оксидативного стресу в щурів, яким моделювали карагінановий хронічний ентероколіт [6]. Активація пероксидного окиснення ліпідів відбувається унаслідок безпосеред- ньої стимуляції генерації активних форм оксигену карагінаном або ж опосередковано, через фрактор некрозу пухлин-альфра [7].

В основі механізму впливу карагінану на організм варто звернути увагу на розвиток оксидативного стресу й запалення як пускових механізмів ушкодження не тільки кишечника, а й основних поліорганних порушень у серці, легенях і печінці.

Метою дослідження було вивчити структурну організацію стінки тонкої кишки, міокарда і печінки експериментальних тварин при застосуванні 1\% розчину к-карагінану.

МАТЕРІАЛИ І МЕТОДИ Дослідження проведено на 24 білих нелінійних щурах-самцях, яких утримували на стандартному раціоні віварію Тернопільського державного медичного університету імені І. Я. Горбачевського. Під час роботи дотримувалися принципів Європейської конвенції із захисту лабораторних тварин. Піддослідних щурів поділили на 2 групи: перша - контроль (інтактні тварини), друга - тварини, які споживали карагінан. Другій групі тварин було забезпечено вільний доступ до 1,0 \% розчину карагінану в питній воді упродовж 1 місяця $[8,9]$.

Фіксацію зразків тканин тонкої кишки, печінки і серця проводили протягом 1 год 1,5 \% розчином глютарового альдегіду в 0,2 М какодилатному бусрері (pH 7,2). Потім зразки промивали какодилатним буфером, повторно фріксували 2 \% розчином чотириокису осмію в тому ж бусрері протягом 1 год. щоб відмити надалі дослідний матеріал від фріксаторів, їх обезводнювали в зростаючих концентраціях етилового спирту. Крім цього, ще обезводнювали в 2-х змінах окису пропілену і поміщали в епоксидну смолу епон-812. Для отримання тонких зрізів використовували ультрамікротом УМТП-6 (алмазний ніж), протягом 15 хв контрастували $2 \%$ розчином уранілацетату і додатково цитратом свинцю за Рейнольдсом [10]. Зрізи переглядали і фотографували за допомогою електронного трансмісійного мікроскопа ПЕМ-100. 
РЕЗУЛЬТАТИ ДОСЛІДЖЕНЬ ТА ЇХ ОБГОВОРЕННЯ При мікроскопічному дослідженні внутрішніх органів експериментальних тварин найвираженіші зміни спостерігали у тонкій кишці. В епітелії слизової оболонки відмічено ознаки дистрофії: вакуолізацію епітеліоцитів, зміну тинкторіальних властивостей їх цитоплазми, місцями відсутність війчастої облямівки. Такі зміни мали вогнищевий характер. Залозисті структури зазнавали атросрії. Домінуючим елементом в картині патологічних змін були прояви хронічного ентериту - інсрільтрація слизової оболонки лімфоцитами, макрофрагами, гістіоцитами, нейтрофрілами, еозинофілами (рис. 1). Запальні інфрільтрати, переважно перивазальної локалізації, візуалізувалися і у підслизовому шарі. Спостерігали помірно виражені явища оріброзу.

За результатами морфометрії тканинних структур стінки кишки виявлено збільшення частки ушкоджених епітеліоцитів - $(19,73 \pm 0,68) \%$ проти $(5,02 \pm 0,13) \%$. Отримані дані співпадають з результатами інших досліджень, які вказують на морфологічну картину запалення при хронічному ентероколіті, який моделювали $1 \%$ розчином карагінану в питній воді [11].

Застосування карагінану зумовлювало зміни морфологічної картини в печінці й серці. У печінці балкова структура органа зберігалася. Спостерігався помірно виражений стромальний набряк. Подекуди мали місце помірно виражені альтеративні зміни гепатоцитів, що проявлялися розвитком дрібнокраплинної жирової дистрофрії - у цитоплазмі клітин візуалізувалися оптично порожні включення (рис. 2). Зазначених змін зазнавали переважно гепатоцити, розташовані у центрі часточок. У перипортальних зонах були наявні двоядерні гепатоцити, що свідчить про репаративну регенерацію в паренхімі печінки.

Зміни серцевого м'яза у піддослідних тварин були помірно виражені. В деяких полях зору поперечну посмугованість кардіоміоцитів визначали нечітко. Спостерігали помірно виражений набряк, місцями повнокров'я судин та наявність поодиноких еритроцитів у перивазальних ділянках. Також подекуди були незначні скупчення лімфроцитів (рис. 3).

ВИСНовкИ Ушкодження епітеліоцитів та їх дистрофрія, дезорганізація сполучнотканинних елементів підслизового шару тонкої кишки при застосуванні 1 \% карагінану приводить до морфологічних змін у печінці (дистрофрічні зміни гепатоцитів) і серці (помірно виражений набряк і вогнищеві скупчення лімсоцитів у міокарді).

Перспективи подальших наукових досліджень полягають у встановленні взаємозв'язків між маркерами оксидативного стресу в печінці, серці й тонкій кишці.

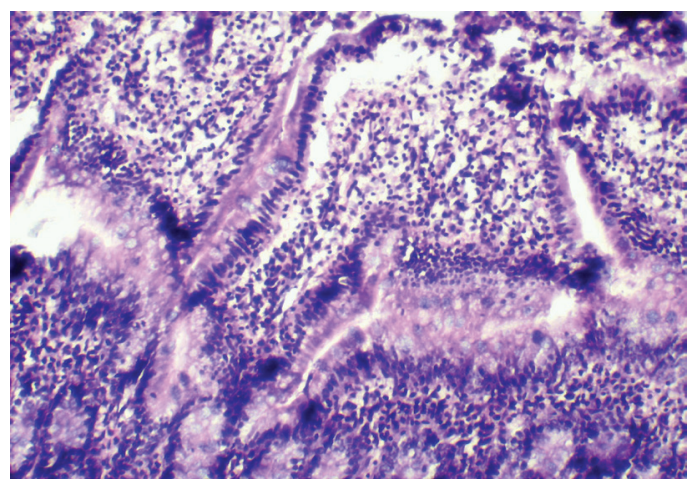

Рис. 1. Слизова оболонка тонкої кишки білого щура експериментальної групи. Інтенсивна запальна інфільтрація. Забарвлення гематоксиліном і еозином. Ок. 10, об. 10.

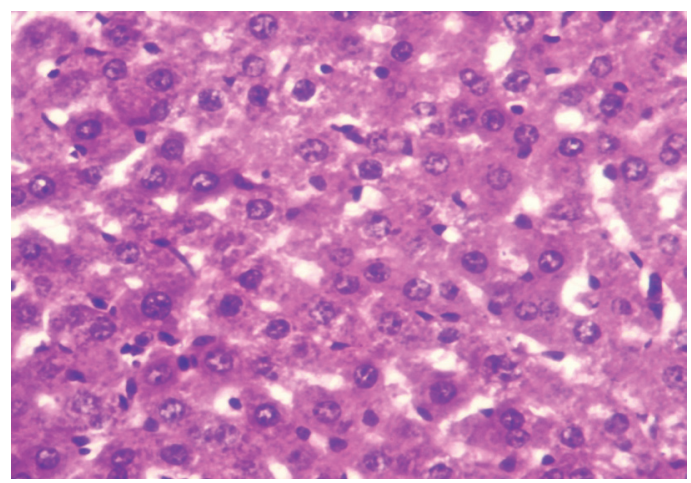

Рис. 2. Печінка білого щура експериментальної групи. Дистрофічні зміни гепатоцитів. Забарвлення гематоксиліном і еозином. Ок. 10 , об. 20

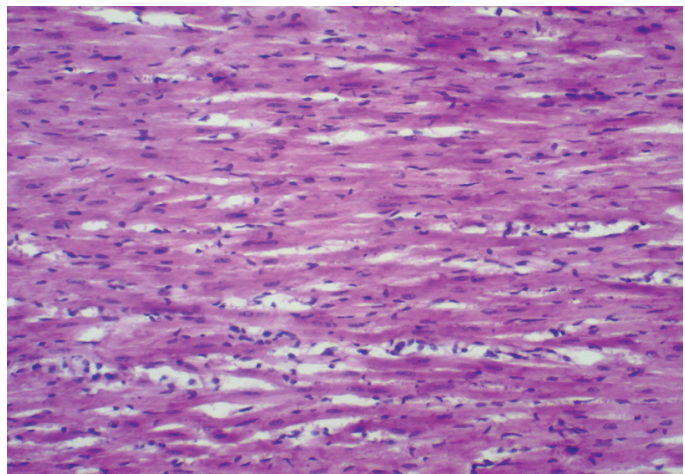

Рис. 3. Міокард білого щура експериментальної групи. Помірно виражений набряк, вогнищеві скупчення лімфоцитів. Забарвлення гематоксиліном і еозином. Ок. 10, об. 20.

\section{СПИСОК ЛІТЕРАТУРИ}

1. Бибик Е. Ю. Анализ спектра пищевых добавок в продуктах питания / Е. Ю. Бибик, Э. А. Яровая // Український медичний альманах. - 2011. - Т. 14, № 2. - С. 20-22.

2. Иммуномодулирующая активность каррагинанов из красных водорослей дальневосточных морей / И. М. Ермак, В. Н. Давыдова, Д. Л. Аминин // Тихоокеанский медицинский журнал. 2009. - № 3. - C. 40-45.

3. Yermak I. M. Chemical properties, biological activities and ap plications of carrageenan from red algae / I. M. Yermak, Y. S. Khotimchenko // Recent Advances in Marine Biotechnology. - 2003. - Vol. 23. - P. 207-255.
4. Eavaluation of in vitro antibacterial anti-inflamatory activity for different extracts of Rauvolfia tetraphylla L. root bark / B. G. Rao, P. U. Rao, E. S. Rao [et al.] // Asian. Pac. J. Trop. Biomed. - 2012. - Vol. 2, No. 10. - P. 818-821.

5. Бойко Ю. А. Фармакотерапевтическая активность геля на основе экстрактивных веществ CAPSICUM ANUUM L. при экспериментальном воспалении / Ю. А. Бойко, И. А. Кравченко, М. Аят // Журнал НАМН України. - 2014. - Т. 20, № 2. C. $257-262$.

6. Розвиток ендогенної інтоксикації у щурів із хронічним ентероколітом а фоні стрептозотоцинового діабету / М. І. Марущак, 
Н. В. Ліснянська, І. В. Пірус, О. П. Мялюк // Вісник проблем біології і медицини. - 2017. - Вип. 4, Т. 1(139). - С. 212-217.

7. Ткаченко А. С. Способ коррекции хронического каррагинаниндуцированного гастроэнтероколита витаминами-антиоксидантами / А. С. Ткаченко, В. Г. Гопкалов, С. Н. Мартынова // Вісник проблем біології і медицини. -2015. - Вип. 3, Т. 1(122). - С. 315-317.

8. Moyana T. N. Carrageenan-induced intestinal injury in the rat - a model for inflammatory bowel disease / T. N. Moyana, J. M. Lalonde // Ann. Clin. Lab. Sci. - 1990. - Vol. 20 (6). - P. 420-426.

9. Пат. 97322. Україна, МПК: G09B 23/28. Спосіб моделювання хронічного гастроентероколіту / Г.І.Губіна-Вакулик, Н.Г.Ко- лоусова, Т. О. Іваненко, Т. В. Горбач, В. О. Коробчанський ; власник Харківський Нац. Мед. ун-т. - № а201014510 ; заявл. 06.12.2010 ; опублік. 25.01.2012, Бюл. № 2. - 4 с.

10. Растровая электронная микроскопия и рентгеновский анализ / Гоулдстейн Дж., Ньюбери Д., Эчлин П. и др. - М. : Мир, 1984. - Кн. 2. - С. 162-317.

11. Стан тонкого кишечника у щурів із хронічним ентероколітом на фроні стрептозотоцинового діабету: патобіохімічні дані / Н. В. Ліснянська, М. І. Марущак, Л. М. Головатюк, Ю. М. Орел // Здобутки клінічної і експериментальної медицини. - 2017. № 3. - С. 105-111.

Отримано 21.12.17

(๐). M. Kopanytsia, Yu. M. Orel, A. M. Shumeliak, M. I. Marushchak I. Horbachevsky Ternopil State Medical University

\section{MORPHOLOGICAL CHANGES OF THIN INTESTINE, LIVER AND HEART TISSUES IN CARRAGEENAN USAGE IN EXPERIMENT}

Summary. According to many scientists, a decreasing in the consumption of fresh and organic food, and the increasing of artificial food additives can be one of the reasons for the increasing in the prevalence of a large number of diseases.

The aim of the study - to learn the structural organization of the small intestine wall, myocardium and liver of experimental animals in the use of $1 \%$ solution of k-carrageenan.

Materials and Methods. The study was conducted on 24 sexually mature white nonlinear male rats. The experimental animals had free access to $1.0 \%$ carrageenan solution in drinking water. Control group of animals received pure water.

Results and Discussion. During microscopic examination of the internal organs of experimental animals, the most pronounced changes were observed in the small intestine. The dominant element in the picture of pathological changes were manifestations of chronic enteritis - infiltration of the mucous membrane by lymphocytes, macrophages, histiocytes, neutrophils, eosinophils. The usage of carrageenan caused changes in the morphological pattern in the liver and heart. Occasionally there were moderately expressed alterative hepatocyte changes, periportal areas observed the presence of dual-core hepatocytes, indicating reparative regeneration in the liver parenchyma. Changes in the heart muscle in experimental animals were expressed moderately. Moderate edema and in some cases, hypertrophy of vessels and the presence of single red blood cells in perivascular areas was observed. Occasionally there were focal concentrations of lymphocytes.

Conclusions. It has been established that consumption of $0.5 \%$ of carrageenan solution in drinking water in rats is accompanied by the damage to the epithelial cells and their dystrophy, the disorganization of the connective tissue elements of the submucosal layer of the small intestine, which leads to morphological changes in the liver (dystrophic changes in hepatocytes) and the heart (moderate edema and focal lymphocyte accumulation in the myocardium).

Key words: carrageenan; small intestine; liver; heart; structural organization.

(๐). М. Копаница, Ю. Н. Орел, А. М. Шумеляк, М. И. Марущак ГВУз “Тернопольский государственный медицинский университет имени И. Я. Горбачевского” МОРФОЛОГИЧЕСКИЕ ИЗМЕНЕНИЯ ТКАНЕЙ ТОНКОЙ КИШКИ, ПЕЧЕНИ И СЕРДЦА ПРИ ПРИМЕНЕНИИ КАРРАГИНАНА В ЭКСПЕРИМЕНТЕ

Резюме. По мнению многих ученых, уменьшение количества потребления свежих пищевых продуктов, органической пищи и увеличение искусственных пищевых добавок может быть одной из причин роста распространенности большого количества заболеваний.

Цель исследования - изучить структурную организацию стенки тонкой кишки, миокарда и печени экспериментальных животных при применении 1\% раствора к-карагинана.

Материалы и методы. Исследование проведено на 24 половозрелых белых нелинейных крысах-самцах. Животным опытной группы был обеспечен свободный доступ к 1,0 \% раствору каррагинана в воде в течении 1 месяца.

Результаты исследований и их обсуждение. При микроскопическом исследовании внутренних органов экспериментальных животных наиболее выраженные изменения наблюдались в тонкой кишке. Доминирующим элементом в картине патологических изменений были проявления хронического энтерита - инсрильтрация слизистой оболочки лимфоцитами, макрофрагами, гистиоцитами, нейтрофилами, эозинофилами. Применение каррагинана обусловило изменения морфологической картины в печени и сердце. Кое-где имели место умеренно выраженые альтеративные изменения гепатоцитов, в перипортальных зонах наблюдалось наличие двухъядерных гепатоцитов, что свидетельствует о репаративной регенерации в паренхиме печени. Изменения сердечной мышцы у подопытных животных были выражены умеренно. Наблюдался умеренно выраженный отек, местами полнокровие сосудов и наличие единичных эритроцитов в перивазальних участках. Также иногда наблюдались очаговые скопления лимфоцитов.

Выводы. Повреждения эпителиоцитов и их дистрофия, дезорганизация соединительнотканных элементов подслизистого слоя тонкой кишки при применении 1\% каррагинана ведет к морфологическим изменениям в печени (дистросические изменения гепатоцитов) и сердце (умеренно выраженный отек и очаговые скопления лимфоцитов в миокарде).

Ключевые слова: каррагинан; тонкая кишка; печень; серце; структурная организация. 